\title{
Decision on the Precambrian-Cambrian boundary stratotype
}

\author{
The Global Stratotype Section and Point for the Pro- \\ terozoic-Cambrian boundary has been agreed upon. \\ The boundary is defined in a coastal section near the \\ lown of Fortune in southeastern Newfoundland. \\ Cancada.
}

\section{Introduction}

The problern of the Precambrian-Cambrian boundary is part of one of the greatest enigmas of the fossil record; i.e. the relatively abrupt appearance of skelclal fossils and complex, deep burrows in sedimentary successions around the world. As will be recounted below, its definition has involved the rolling back of a major fronticr in geology over the last three decades.

Until the late 1940s. it was assumed that the Precambrian was largely without fossils and that the base of the Cambrian was marked by the lowest appearance of trilobites. e.g. the 'Olenellus Zone' of Walcott (1890) and Wheeler (1947). More traditionally, it was drawn al a regional unconformity below them, c.g. in Rayner (1967). The lirst steps towards a more precise definition of the base were tiken in 1960. at the Norden IGC in Copenhagen. when M F Glaessner proposed the establishment of a Subcommission on Cambrian Straligraphy, and in 1968 when Chairman C J Stubbletield and Secretary J W Cowie chose the problem of the 'Base of the Cambrian System" as one of its first tasks. By this time, the existence of a latest Precumbrian fauna was widely acknowicdged, e.g- in Glaessner and Wade (1966), and work by Russian geologists was beginning to demonstrate a pre-trilobitic succession of skcletal faunas, which werc referred to the Cambrian System. e.g. in Rozanov (1967). Meelings on the boundary were organized for the IGC in Czechoslovakia in 1968. and at Montreal in 1972. Much discussion ensued at the latter meeting and a 'Working Group on the Precambrian-Cambrian Boundary' (PC-CBWG) was formed, with J W Cowie as its Chairman. Some of the history of the Working Group has becn summarized elsewhere (Cowie, 1992).

In effect, this Working Group was selting itself the challenging task of delining the 'bottom line' of the biostratigraphic scale; i.e. to discover, name and interpret fossils where few had been found before. Many of the fossils unearthed over the following decades were not referable to previously known groups and their potential for stratigraphic correlation was, therefore, completely untested.

The Working Group held its first lield meeting in Sibcria in 1973. sponsored by the Academy of Sciences of the USSR. 10 consider possible stratotypes for the Precambrian-Cambrian boundary along the middle reaches of the Aldan and Lena rivers in Yakutia, eastern Siberia. Here, 28 foreign geologists were introduced to the 'Tommotian launa' and the sections of Rozanov and others (1969). Members discussed, not for the last time, the origin of the lowest sinall shelly fossil (SSF) assemblage in bed 8 at Ulakhan Sulugur, that was referred to the base of the Tommotian Stage (Cowie and Rozanov, 1974). Discussions also focused on the relationship between lithofacies and biofacies, notably the problem of correlating carbonate shelf facies with archaeocyathans (as in Siberia) with clastic shelf to basinal facies that pre- dominale elsewhere. It wats for this reason that B Daily (unpublished) emphasised the polential of Irace fossil stratigraphy as a subsidiary guide.

This was followed in 1974 by a meeling in Paris, at which the following points were unanimously agreed (Cowic. 1992).

- The primary lask of the Working Group was the choice of a stratolype boundary point; a secondary lask was the consideration of associated stratigraphic divisions above and below the boundary.

- Any succession selected for the boundary point must be as continuous as possible, marine, and as monofacial as possible: the main method of guidance in selection should be biostratigraphy although all possible methods of correlation should be enlisted.

- The 'Ediacaral' type fauna should be considered as Precambrian.

- The "olencllid/tallotaspid" trilobite faunas should be considered as Cambrian.

- Between the "Ediaciara" and the trilobite faunats, those fossiliferous successions that could not be allocilled with certainty to either the Precambrian or the Cambrian. should have the Working Group's close attention.

Increased support for work on the boundary was made possible in 1974. when 'The Precambrian-Cambrian Boundary' was accepted as Project 29 by the IGCP Board. A meeting in Canbridge. UK. in 1978. reviewed discoveries of sub-trilobitic small skeletal fossils and trace fossils from around the world, as well as the potential of magnetostratigraphy. The Cambridge meeting recommended to the Working Group that "The PrecambrianCambrian boundary should be placed as close as is practicable to the base of the oldest stratigraphic unit to yiedd Tommotian (sensu lato) fossil assemblages" (Cowie, 1978). Although there was little support at this time lor a boundary defined by trace fossils. Iheir potential for the correlation of strata below the first trilobites was now being explored (see Alpert, 1977; Brasier, 1979, figure (1).

Candidates for the Precambrian-Cambrian GSSP were discussed in some detail al a mecting in Bristol, England in 1983. and three were selected for lurther consideration, as follows.

- Ulakhan-Sulugur on the Aldan River in castern Siberia, of the former USSR (now in Russia); here the boundary level (at the base of bed 8) lay in carbonate facies, within a succession of small skeletal fossiis and algac that lay below the earliest archaeocyathans, brachiopods and other markers of 'Tommotian lype'; this section was well known and well studicd.

- The section at Meishucun near Kunming, in Yunnan Province of southern China. Here, the boundary level (Marker B) lay within a phosphorite facies and was marked by the abrupt appearances of phosphatised micromolluscs and problematica. This section was well-studied but little known outside of China.

- Several sections on the Burin Peninsula of southeastern Newfoundland, Canada; here both sinall skeletal fossils and trace fossils were known to oceur in a mixed carbonate-siliciclastic succession. Only outline studies were available from this region and no precise section was pinpointed.

At this meeting, it was again decided that the boundary stratotype should be placed "as close as practicable to the lowest known appearance of diverse shelly fossils with a good potential for correlation" (Cowic, 1985). Such an emphasis upon SSFs provided a great 
stimulus to their study. hut there was growing concern about their utility for correlation. A preliminary mandate for the Meishucun section was deferred al the Moscow IGC in 1984, when it was recognised that greater international agreement on SSF taxonomy was necessary. This led to an 'SSI. Workshop' in Uppsalit in 1986, organized by $S$ Bengtson. It can now be seen that this meeting resulted in several new thrusts. First, it hecame appirent that the boundary successions in Chinal had a distincl character, which could be traced into India. Pakistan and Iran (Brasier, 1989al) but comclation beyond these former terranes of Gondwana wals more problemalical. Second. it encouraged the view that small skeletal fossils were longranging, highly variable. over-split taxonomically, taphonomically poorly understood. olten restricted by licics and provincial in distribution (Landing and others. 1989); Qian and Benglson, 1989). Altempts were mude to dratw the dilla on pandemic forms together. comparing the first appearances of successive laxal on al global scalc (e.g. Brasier, 1989b) but the results were not entirely encouraging for high-resolution straligraphy. The problems of SSI's were beginning lo come into focus.

Knowled ge about the Chinese sections improved after visits by Group members in the late 197()s and early 1980s, and mos( especially after publications in English (L.uo and others, 1984; Xing and others, 1991) and the international meeting on the Terminal Precambrian and Cambrian Systems al Yichang in 1987. The problems of correlating the three sub-trilobitic matrkers all Meishucun (termed $A$. $B$ and $C$ ) were reviewed in English by Brasier (1989a). Scientists outside China showed considerable concern about tive lactors relalling to the GSSP' candidale at Meishucum.

- The comparative age of the Zone II assemblage above Marker B, chosen by the Chinese as the eandidate boundary point: this question arose becaluse it was thought to contain fossils lound above the Tommotian in Siberia (Bengtson and others. 1984).

- The presence of a possible gap just below Marker B. shown by an abrupt change in lithoficies (e.g. Bratsier, 1989 il: lainding. $1094)$.

- The lack of litunal continuity between the three markers, also sugrgestive of breaks in the sequence (Qian and Bengtson. 1989 ).

- The interpretation of carbon isotopic proliles reporled by Brasier and others (1990). For eximple. Kirschvirok and others (1991) suggested that \%one II miglut correlate with the hasal Aldabanian excursions in Siberia.

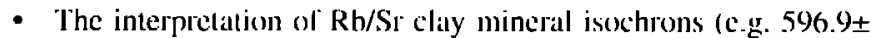
4.6 Ma, Xing and others. 199) 1): recent data from U-Pb isochrons lrom ash baunds near Matrker $B$ indicalte a much younger age of 525 7 Ma (Compsion and others. 1902).

Further documentation also becianc available on the Siberian sections (Sokolov and Zhuravleva, 198.3; Royanov and Sokolov. 1984) and some members of the Working (iroup were able to exilmine the CSSP at Ulakhan-Sulugur Juring the Second International Symposium on the Cambrian System in 1990 (Astishkin and others. 199()). Its potential for carbon isotope- and magnetostraligraphy appeared good (e.g. Kirschvink and others. 199) ). Discussion, however, centred on the origin ol bed 8 : wast it al stratified layer, or was it piped down along kalrstic lissures lirom about al melre above'? Support for the latter view was given by licld clata (Khomentovsky and ollers, 1990) but isotopic dala hats proved more equivocal (Brasier and others, 199.3). A view is emerging of at widespread unconformily near the base of the Tommotian across nuch of the Siberian Platform, representing a hiatus of uncertain duration (e.g. Linding. 1994).

Until 1983, the potential ol southeatstern Newloundland for at mixed. carbonale/SSF-siliciclastic//race-lossil stratigraphy was little lested. Hutchinson (1962) and (ireenc and Williams (1974) hatd reported SSF alssemblitges below the carliest trilobiles. T P Fleteher (1978) had presented an outline stratigraphy of the Burin Peninsula at Cambridge. This work was followed up by further litho- and biostratigraphy (T P Filetcher, unpublished), accompanied by magnelostratigraphy (J Kirschvink. unpublished). The latter discovered. however. that the whole section was remagnelised in Ordovician limes. A Working Group visit to the Burin Peninsula in 1979 was followed up by important ground work on SSFs, trace lossils and lithostratigraphy (Bengtson and Fletcher, 1981. 1983). Further researches culminated in a series of papers which detailed the stratigraphic distribution of trace fossils. SSF's and lithostratigraphy (Crimes and Anderson. 1985: Narbonne and others. 1987: Narbonne and Myrow, 1988; Landing, 1988; Landing and others, 1989).

An understanding emerged that SSFs. which had hitherto provided the focus of Working Group discussions, were very greatly al fected by provincialism and a virtual restriction to shallow carbonate facies. This suggested, to some, that delinition of the boundary might be betler guided by t'ace lossils as well as body fossils. The advantages of trace fossils were stressed to be als follows (e.g. Crimes. 1987: Narbonne and others. 1987: Natromne and Myrow 1988).

- They are especially common in siliciclastic liacies. in which SSI:s are typically rare and poorly preserved. This is important since these deposits comprise nearly 70 per cent of exposed rocks in the boundlatry interval.

- Cambrian trace lossils appear to have been less restricted in terms of habilat range than in later intervals.

- Several successive trace fossil zones from around the workl may be recognized in strala below the lowest trilobites.

- These zones include ichnogenera with a limited stratigraphic lange and a broad stratigraphic distribution. Of these, the Phycodes pedum Zone assemblage contains lypical Cambrian ichnotaxa in a high-diversily assemblage with branched morphologies, complex leeding burrows, escape traces and awelling burrows. The underlying Harlaniclla podolica Zone assemblage is of lower diversity and comprises simple, horizontal, sediment-feeder traces, e.g. Nenoxites, Palaropascichnus.

- The ranges of Harlaniella podolica and Phroodes pedum are believed not to overlap; onc stlcceeds the other: providing a rare example of faumal replacement within a boundary succession.

- At Fortune Head, Burin Peninsula, these two traces are seen within it stratigraphic succession that shows little evidence of environmental change. Correlations of the boundary level are also possible between Fortune Head and other localities on the Burin Peninsula. Similar launal changes were purported to lake place at other localities around the world.

These ideats were discussed al a meeting al St John's. New foundland in August 1987. and followed by field excursions through the "Terminal Proterozoic" and lower Cambrian (Narbonne, 1987). By this time, the Working Group was under some pressure to reach a decision, because it had examined the problem since 1972. It was also clcar that whilst it might be possible to reach a decision on the boundary point, its global correlation wats going to be open to wide dispute. Non-biostratigraphic methods of correlation. such as carbon-, strontium-, event-stratigraphy and geochronology would be needed to improve stratigraphic resolution at this level. A proposal was put forward. therefore, by $M$ D Brasier and $\mathrm{K} J$ Hsu to the IGCP Board in 1989, to encourage such researches through a project on Precambrian-Cambrian Event Siratigraphy”. Project 303 was accepted and its first meeting took place in Siberia in July-August 1990. The findings of this project have an important bearing on correlation of the Precambrian-Cambrian boundary. which will be discussed elsewhere.

The chosen GSSP candidate al IForlune Head, Burin Peninsula. Newfoundland was first put lorward by Canadian and US members of the Working Group in 1987. The results of a straw poll held in St John"s at that time seemed lavourable (Cowic and Brasier; 1989). Written proposals were then requested by Chairman J W Cowie from each of the three GSSP candidates. to outline their utility for correlation by biostratigraphic and non-biostratigraphic (e.g. geochronologic, palacomagnetic and stable isotopic) lechniques. 
for accessibility. and potential for conservation. These were submilled in October 1990) as follows: A Yu Rozanov (Ulakhan-Sulugur): Xing $Y$, Luo, $H$, Jiang. $Z$. and Zhang, $S$ (Meishucun): and $E$ Landing and $G$ N Narbonne (Fortune Head, Newtoundland). A postal ballot of the 23 Voting Members was arranged by J W Cowic in the Spring of 1991. This ballot received a 100 per cent response, giving an overall majority of 52 per cent to the Burin candidate. 35 per cent to China and 1.3 per cent to Siberia. Following the guidelines ol ICS. a second postal ballot was held on the Burin section alone, in the summer of 1991, which led to a 61 per cent majority lor the section al Fortune Head. This majority was large enough to allow ratification by the ICS and the IUGS (al the IGC in Kyoto, August 1992), when Chairmanship of the Cambrian Subcommission passed to M D Brasier. Responsibility for the basal boundary of the Cambrian also passed from the Working Group to the Cambrian Subcommission al this time.

\section{The Fortune Head GSSP}

The Fortune Head GSSP section is situated near the tip of the Burin Peninsula. southeastern Newloundland (figure 1), in low clifls that extended beyond 'Fortune Dump'. Easy access is possible from the town of Fortune; there are no political or gengraphical problems of access. The stratolype was piclured in Episodes of December 1987 (Narbonne, 1987, figure 1).

Coastal eliff exposures at Fortune Heald display some $440 \mathrm{~m}$ of the Chapel Island Formation. with beds dipping at 15 io 46 degrees to the west (steeper dips are loward the top of the section). Several small fiults are present well above the strattotype level, but marker horizons allow easy correlation across them (Landing and others. 1988. p.35). Breaks in deposition are minor and restricted to the bases of thin, wave-deposited sand units.
In this region, Cambrian deposition (Figure 2) was accommodated by local, long-term extension of the basement, comprising Late Precambrian volcanics and clastics alfecled by the "Avalonian Orogen". The fortune Bay Batsin begall with the deposition of $2750 \mathrm{~m}$ of upwardly fining red beds that grade into poritidal sandstones at the lop (Bengtson and Fletcher. 1983: Lainding and others, 1988). These were succeded by ea. $1000 \mathrm{~m}$ of siliciclastic shelf lacies, placed in the Chapel Island Formation, and deposited during a major "sea level' cycle as follows: peritidal sandstone and shales (Member 1): storm-influenced muddy deltaic and shell sandstones and mudstones (Member 2A): thinly laminated siltstones of the distal shell, deposited below wave base (Member 2B and Member 3): mudstones with thin limestones. deposited under low energy, inner shelf to peritidal conditions (Member 4): and sandstones and siltstones of an oflshole 10 shoreface storm-dominaled shelf (Myrow and Hiscoll, 1994). These were then capped by the macrotidal sandstones and siltstones of the Random Formation, which can be traced across the Avalonialn region (Hutchinson, 1962; Landing, 1992).

Member 1 of the Chapel Island Formation (ca. 180 (n) includes uppermost Precambrian sediments. It yields biostratigraphically important trace lossils of the Harlamiclla podolica ichnofossil Biozone (Bengtson and Fletcher, 1983; Crimes and Anderson, 1985). Larlamiella podolice and Palaeopascichmes delicatus range into Member 2, where they are last seen $0.2 \mathrm{~m}$ below the GSSP. Organic-walled tubes of Sabellidites cambrionsis lirst appear near the lop of Member I and range al least ats high as Member 4. The Sabellidites cambriensis skeletal lossil Biozone is delïned between the first occurrence of this lixon, and the higher first appearance of calcareous lube 'Ladahere' cylindrica in Member 2B.

The Precaunbrian-Cambrian boundary point (Figure 3) lies $2.4 \mathrm{~m}$ above the base of Member 2 in the Clapel Island Formation.

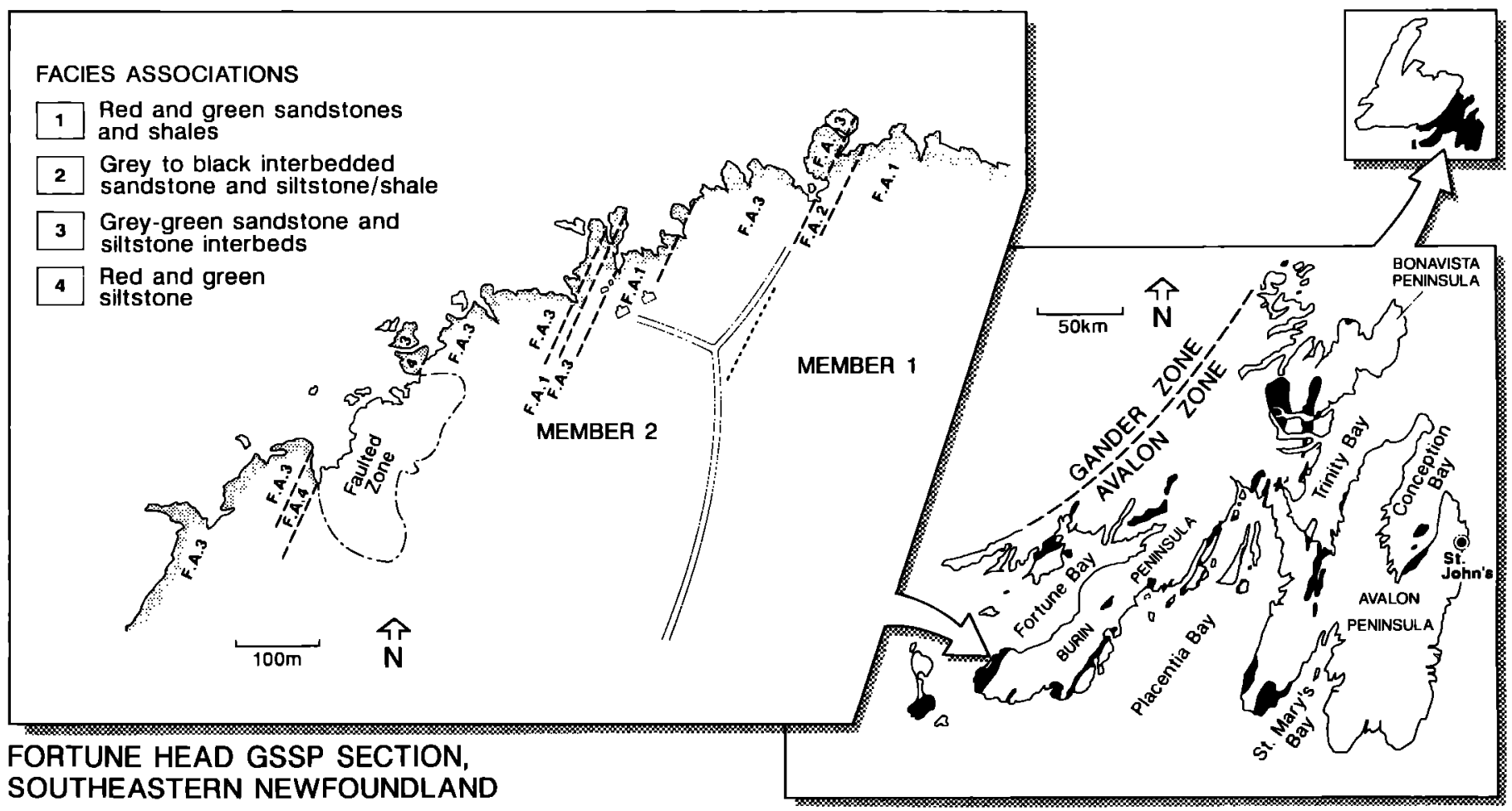

SOUTHEASTERN NEWFOUNDLAND

Figure I Generalized locality map of Newfoundland (inset) showing location of the Fortune Head stratotype and detail map of the $\mathbf{4 4 0}$ m-thick section at Fortune Head. Diagonal ruling indicates strike direction. $F A=$ facies associations. Based on landing and others (1988, figures 4 and 19). 


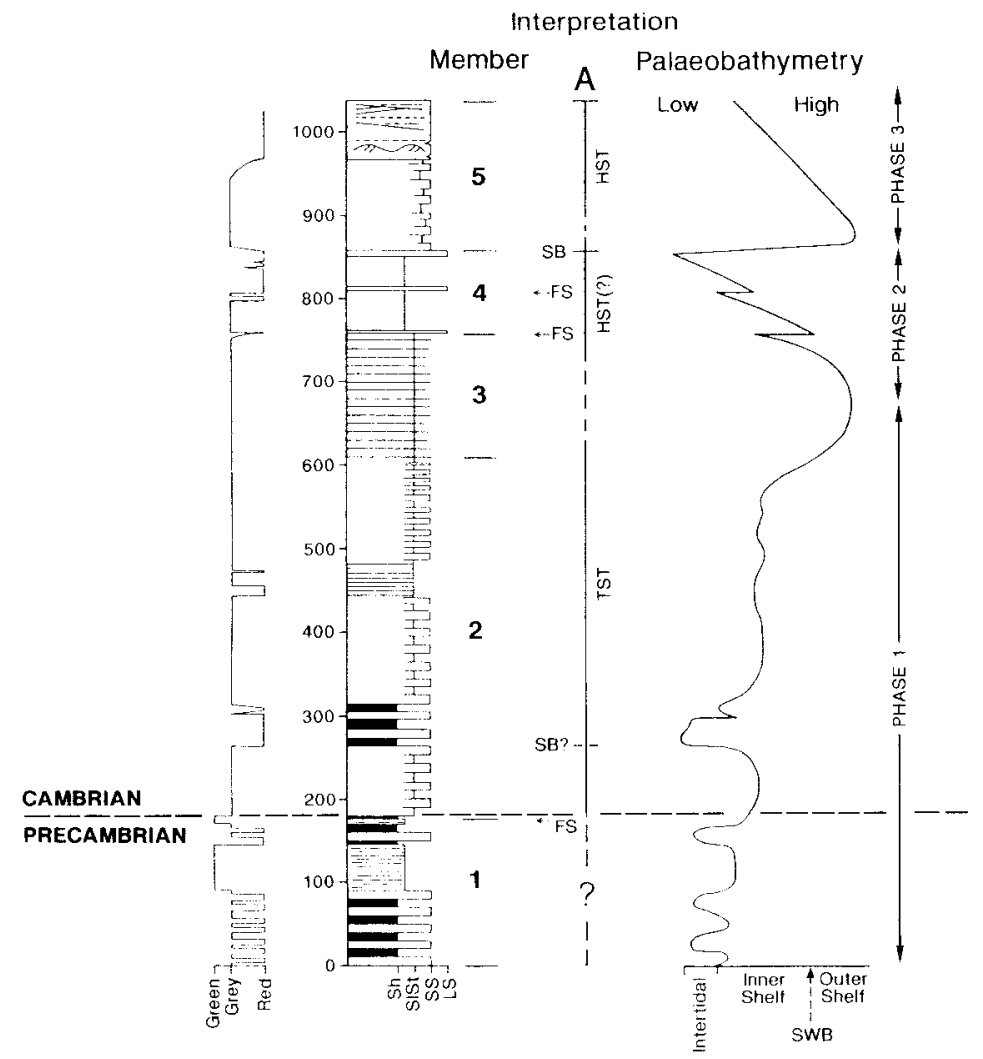

Figure 2 Generalized stratigraphic section for the Chapel Island Formation, showing inferred paleobathymetry, threephase depositional history, and sequence-stratigraphic interpretation. The Precambrian-C'ambrian boundary stratotype point is shown. FS = flooding surface; $M F S=$ maximum flooding surface. $S B=$ sequence boundary. $T S T=$ transgressive systems tract. HST = highstand systems tract. $\mathrm{SWB}=$ storm wave base. $\mathrm{Sh}$ $=$ shale; Sltst = siltstone; $S S=$ sandstone; $L S=$ limestone. The scale is in metres from the beginning of the exposure. Based on Myrow and Hiscott (1993, figure 3)

i.e. just above the transition 10 storm-inlluenced facies and $18.2 \mathrm{~m}$ above the base of the succession at Forlune Head. This GSSP is a point in rock that defines a moment in time and was selected with guidance from the level marked by the lowest occurrence of Phycodes pedum (a trace fossil), at the base ol the Cambrian Phvcodes pedum Biozone (Figure 2; see Narbonne and others, 1987, ligure 8B). The marker fossil is preserved as a serics ol branched, hypichnial ridges on the lower surlace of a sandstone. Its appearance at this level is not directly traceable to a change in facies, which takes place lower in the sequence (Member I to Member 2A boundary). In addlition. both peritidal and subtidal facies in Member I contain Harlaniella poclolica. and facies identical to those in Member 1 are interbedded within Member 2A, but do not show upper Precambrian trace fossils. These leatures suggest that environmental factors, while signilicant, were only of second-order influence upon the distribution of trace fossils though this section. The houndary point also defines the base of the lower Cambrian "Placentian Series" of Landing and others (1989).

The first occurrence of calcareous shelled skeletal lossils ('Ladatheca' cylindrica) here lies some $400 \mathrm{~m}$ above the Precambrian-Cambrian boundary. As mentioned above, their appearance is related to facies and laphomomic conditions and is unlikely to mark the true origin of biomineralization. Trilobites appear some $1400 \mathrm{~m}$ above the boundary point, and mark the start of the Lower Cambrian 'Branchian Series' of I anding (1992).

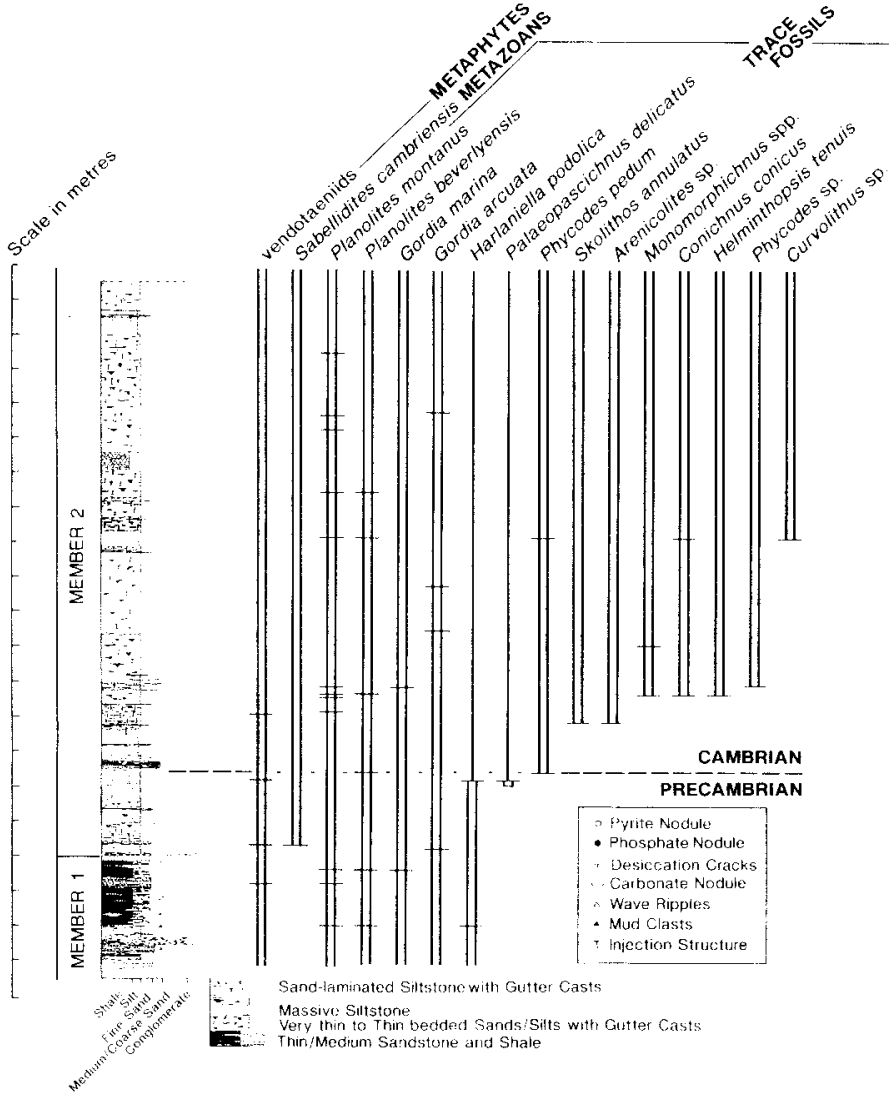

Figure 3 Faunal succession and lithology through the Precambrian-Cambrian boundary stratotype section at Fortune Head. Based on Narbonne and others (1987, figure 5) and Landing and others (1988, figure 20). For fossil distribution and lithological data from the overlying $420 \mathrm{~m}$ of continuously exposed strata at Fortune Head, see Narbonne and others (1987, figure 4), Landing and others (1988, figures 2I-23); Myrow and Hiscott (1993, figure 8).

\section{Non-biostratigraphic means of correlation}

The boundary level lacks carbonates suitable for carbon or strontium isotope analysis. Studies on nodules and bedded limestones higher in the Burin succession show the effects of widespread thermal alteration during deep burial and granitic intrusion (Brasier and others, 1992). Similar problems have affected suitability of the stratotype for palacomagnetic correlation (sce above). Regreatably, this means that the Asiatic sections of Siberia and China cannot be correlated with the new GSSP by means of carbon isotope- and magnetostratigraphy, although they provide a valuable tool for correlation elsewhere (Kirschvink and others, 1991: Brasier and others. 1994).

\section{Geochronology of the boundary}

Recent U-Pb radiometric determinations on volcanic circons are available from New Brunswick, in strata possibly correlated with the upper part of Member 5 (Bowring and others, 1993). These yield a date of $530.7 \pm 0.7 \mathrm{Ma}$ (Isachsen and others. 1994); previously reported as $531 \pm 1$ Ma by Bowring and others (1993) and Landing 
(1994) and provides a maximum age for the base of the overlying quartzite lormation. The boundary point lies some $80(0 \mathrm{~m}$ below its possible correlative, the Random For Ination. in the Burin Peninsula.

A further guide to the radiometric age of the PrecumbrianCambrian boundary comes liom recent U-Pb dates from Siberial (Bowring and others, 1993). In the Olenek region. volcanic breccias oceur within the Nemakit-Daldynian Stage, above the first small shelly fossil (Cambrotubulus sp.) but below the first skeletal assemblage with Anabarites irisulcatus. These breccias have recently been

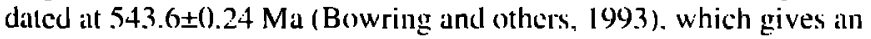
estimaled ange for the balse of the Nemakil -.Daldynian of aboul 544 Ma. This level has been correlated with the base of the Cambrian in Newfoundland (Narbonne and others, 1987), on the following grounds: occurrence of Phycodes sp. al an unspecified level within the Nemakil Daldynian (Fedonkin. 1987; actually this taxon maly not appear until the middle of the stage: M A Fedonkin. pers. comm.. 1993); occurrence of Sabellidites combriensis. which ranges from the base of the stage (Sokolov and Fedonkin. 1985). A provisional estimale for the age of the Precambrian Cambrian boundary is, therefore. cal. $5+4 \mathrm{Ma}$.

\section{Acknowledgements}

The following are thanked for comments and contributions to this report: T P Crimes, T P Fletcher, E Landing. and A R Palmer.

\section{References}

Mlpert. S P. 1977. Trace lossils and the basal Cambrian boundary, in Crimes, T P. and Hatrper. J C, cols.. Trace l'ossils 2: Geological Jourmal Special Issite. 9. Seel House Press. Liverpool. pp. 1-צ.

Astaskikin. $\vee \wedge$ and seven others. 1990 , Guidebook for excursion on the Aldan and I enal Rivers. Siberian Plallorm. Novosibirsk. 11.5 p.

Benglson. S, and litelcher. 1' P. 1981. The succession of skeletal forssils in the hasal L.ower Cambrian of southeastern Newloundlind, in Taylor. M I:, ed.. Shon Papers for the Second International Sympesium on the Cam. brian System: United Stales Geological Survey Open-Fïle Report. $81-74.3,18 \mathrm{pp}$.

Benglwon. S, and lietcher. T P, 1983. The oldest secpuence of skelelal lossils in the lower Cambrian of soulheistern Newloundland: Cimadian Journal ol Farlh Scicnces, v. 20, pp. 523-.526.

Bengtson. S. Missirzhersky. V V. and Rozanov. A Yu. 1984, The Precambrian-Cambrian boundary: a pleal for calution: IGCP Project 29 Circular Newslever. June 1984. pp. 14-15.

Bow ring. $S \wedge$, Grotzinger. J P. Isalthsen, C E. Knoll. $\wedge$ H, Pelechaly, S M. and Kolosov, P. 1993, Calibrating rattes of carly Cambrian cvolution: Sciencic. v. 261. . . 1293. 1298.

Bratsier, M D, 1979. The Cambrian radialion event, in House. M R. ed., The Origin of Maijor Invertebralle groups. Acaddemic Press. Londen. pp. $10.3-1(0)$.

Brasier. M D, 1989at, Chind and the Paldieolethyan Belt (Indial. Pakistun, Iran, Kirzakhstinn, and Mongulial). in Cowie, J W. and Brasier, M D, ecls.. The Precimbrian-Cimbrian Boundary: Oxford Universily Press, jp). 4(0.74.

Brasier, M I). 1989h. Towards a biostraltigraphy ol the curliest skeletal hiolas, in Cowice. J W. and Brasier. M D. eds.. The Preciambrian-Cambrian Boundary: Oxlord Universily Press. pp. 40-74.

Brasier, M D, Anderson, M M, and Corlield, R M, 1992, Oxygen and carbon isotope straliglaphy of carly Cambrian carbontates in soulheastern Newloundland and England: Geological Magakinc, v. 129. pp. 26.5-279.

Brasier. M D), Khomenlovsky, V V, and Corficld, R M. 1993, Stible inolopic calibration of the carliest skiteletal ansemblages in eastern Siberia (Precaumbriaul-('ambriaun boundialy): Terra Novia, v. 5. pp. 225-2.32.

Brasier, M D. Corlicld, R M. Derry, L A. Rosanov. $\Lambda$ Yu, and Zhuravlev, $\Lambda$ $Y u, 1994$, Multiple $S^{1.3} \mathrm{C}$ excursions spanning the Cumbrian explosion to the Botomian crisis in Siberia: Geology, v. 22, pp. $455-458$.

Brasier, M D, and nine others 1990, The carbon- and oxygen-isolope record of the Precambrian-Cambrian boundary interval in ('hinat and Iranl and their correliation: Geological Magazine, v. 127, pp. 319-332.

Compsion. W, Williams, I S. Kirschvink, J 1., Zhang Z.. and Ma, G. 1992. Zircon U-Ph ates from the Early Cambrian time-scalle: Journal of the (ieological Socielj, 1. 1+9. 171-184.
Cowic, J W. 1978, IUGS/IGCP Project 29 Preciumbrian-Cumbrian Boundary Working Group In (ilnbridge. 1978: (icological Magazine, v. 115. pp). 1.51-152.

Cowic, J W. I985, Continuing work on the Precimbrian-Cambrian boundary: I:pisodes, v. ห. pp. 93 -97.

Cowite, J W. 1992. Two decades of resederch on the Prolerozoic-Phaneroyoic Iransilions: 1972--199),

Cowic, J W. and Ro/anow. A Yu. 1974, 10 (j) Precambrian-Cambrian Boundary Working Group) In Siberia: Geological Maga/ine. v. 11 1. pp. 237-252

Crimes, T P. 1987. 'lratce fossils and correlation of 1 atle Preceambrian and liarly Cimbrian stralta: Geological Magiaine, v. 124. pp. 97-119.

Crimes. T P. and Anderson, M M, 1985, Trace fossils from Lalle Precambrian-carly Cambrian strala of southeasilern Newloundland (Canada): lomporal and envirommental implicintions: Jourmal of Palcenlology, v. 59. $310-3+3$.

Flecther, T P. 1978. in Uniled Kingelom Contribution to the Intenational Geological Correlition l'roggiamme. (9)76-78 Report: The Royal Society. Londonl. pp. 26-27.

Glitessner, M I: and Wadc. M. 1966, The lale Pre-Cambrian fossils from Ediacara, South Australia: Palatenlology. v. 9. pp. 599-628.

Greene, B, and Willians, 11, 1974. New lessil locialilies and the hase of the Cambrian in southeastern New foundland: Cantdian Journal of Earth Scicnces, v. I1, pp. 319-323.

Hulchinson, R D, 1962, Caunbrian stratigraphy and trilobile fiunus of southeastern Newfoundiand: Bullein of the Geologieal Survey of Canada. 88. $1.56 \mathrm{p}$.

Khomenlovsky, V V. and Karlovit, G A. 1993. Biostratigraphy of the Vendian-Cambrian beds and lower Cannbrian boundary in Siberia: Geological Magatzine, v. 1.30, pp. 29-45.

Kirschvink. J. Magatril\%. M., Ripperdan, R 1, /huravlev, A Yu. and Rozanov, A Yu. 199), The Precaumbrian/C inbbrian boundary: milgnetosiratigraphy and carbon isotopes resolve correlation problems between Siberia. Morocco and soull Chini: GiSA Todlay. v. I, pp. 69-71,87.91

Landing. I: 1986, L uwer Cambrian of eastern Massachuseds: stratigraphy

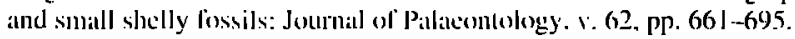

Landing. 1 . 1992. I.ower Cambrian of southeitstern Newfoundland:

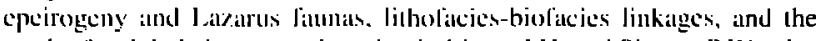
nyyth of a global chronostratigraphy, in l.ipps, J H. and Signor. P W, tds.., Origin and Eatrly Evolution of the Metizoit: New York. Plenum Press, pp. $28.3-3(19)$.

Landing, I:. 1994, Precambrian-C ambrian houndary global stralotype ratilied and a new perspective of Caunbrian lime: Geology, v. 22, 174)-182.

l.anding. L: Myrow'. P M. Benus. A P, and Narboune, G M. 1989. The Platcentian Series: appeatrance of the oldest skeletalized fiannas in southeastern New loundland: Journal of Pialieontology. \&. 6.3. pp. 739-769.

Landing, E., Narbonne, G M. Myrow, P. Benus, $\wedge$ P, and Anderson, M M, 19KK, Fatunas and deposilional environments of the upper Preciunbrian through lower Cambrian. southeasisern Newloundland: New York State Muscum Bulletin, v. 463. p). 18...52.

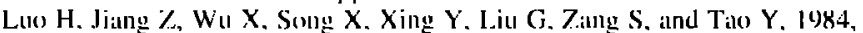
Sinian-Canbrian houndary candidalc all Meishucun. Jinning. Yunnsun. China: 'The People's Publishing Ilousc, Yuming, If pp.

Myrow, P, and IJiscoll, R N, I993, Deposilional Jistory and sequenee sloal ig raphy of the Precambrian-Cambrian boundary stratotype section. Chapel Island formation. southeistern Newfoundland: Palateogeography, Pallateoclimatology. Palacuecology. v. I(2), pp. 1,3-3.35.

Narbonne, (3 M, 1967, Trace lossils, small shelly liossils and the Precambrian-Cambrian Boundary: Ejpisodes, v. 10, 339-340.

Narbomne. (; M, and Mylow, P, 1988, Trace fossil biostraltigraphy in the Precambriau-Cambrian boundary inlerval: N'w York State Muscum Bulletin, 46.3, pp. 72-76.

Narbonne, G M, Myrow, P, I anding, E, and Anderson, M M, 1987. A candidate stratetype for the Precambrian-Cambrian boundary, Forlune Head, Burin Peninsulat, southeissern New foundland: Canadian Journal of Earth Sciences, v. 24, p. 156.

Qian Y. and Bengtson. S. 1989, Paliteonlology and biostraligraphy of the Meishucunieun Stage in Yunnin Provinec, south China: Fossils and Strata, v. $24,156 \mathrm{pp}$.

Rayner, D. 1967. The SIratigraphy of the British Isles: Cambridge Universily Press, London.

Rozanov, $A$ Yu, 1967. The Cambrian lower boundary problem: Geological Magildinc. v. 104, pp. $415-434$.

Rozanov, A Yu, and Sokolov, B S. 1984, Lower Cambrian slage subdivision: straligraphy: Akindemii Nauk SSSR, Moscow. ladaltelslvo "Naukat. (In Russian).

Rozanov, $\Lambda$ Yu, und nilue others. 1969. The Tommotian Stage and the Cambrian Lower Boundary l'roblem: Akiddemial Nauk SSSR. Orclenal Tru- 
dovogo Krasnogo Zhumeni Geologicheskii Instituta, no. 206, 380 p. (In Russian).

Schopf, W J, and Klein, C, 1992, The Proterozoic Biosphere: Cambridge University Press.

Sokolov, B S, and Zhuravleva, I T, 1983. Lower Cambrian stage subdivision of Siberia. Atlas of fossils: Akademii Nuak SSSR, Moscow, Trudy Instituta Geologii i Geofyziki, v. 558. (In Russian).

Walcott, C D, 1890, The fauna of the Lower Cambrian or Olenellus Zone: Tenth Annual Report of the Director, 1888-1889, US Geological Survey, Part 1.

Wheeler, H E, 1947, Base of the Cambrian System: Journal of Geology, v. 55 , pp. $153-159$.

Xing Y, Luo, H, Jiang, Z, and Zhang S, 1991, A candidate global stratotype section and point for the Precambrian-Cambrian boundary at Meishucun, Yunnan, China: Journal of China University of Geosciences, v. 2, 47-57.

Dr Martin Brasier is Chairman of the Subcommission on Cambrian Stratigraphy and Leader of IGCP Project 303 on Precambrian-Cambrian Event Stratigraphy. His research currently concentrates on the potential of carbon and strontium isotope stratigraphy for improved stratigraphic resolution of the late Precambrian-Cambrian events, and on environmental changes associated with plate movements (eastern Asia to Avalonia). He lectures in the Earth Sciences Department at Oxford, and is a Fellow of St Edmund Hall.
Dr J W Cowie has served as Secretary of the Cambrian Subcommission (1964-1992), Chairman and Project Leader of the Precambrian-Cambrian Boundary Working Group (19721992) and as Chairman of the International Commission on Stratigraphy (1984-1992). Ongoing activity includes work with the IUGS Geological Database on Geological Sites (IUGS GEOSITES) and as Geological Advisor to World Heritage.

Dr Michael Taylor, Secretary of the Subcommission on Cambrian Stratigraphy, is a research geologist with the US Geological Survey, Denver. His current research interests include early Palaeozoic trilobite and mollusc biostratigraphy, biofacies analysis and carbonate depositional environments. He has developed an ecological model for explaining the global distribution of trilobite faunas in relation to stratified ocean systems.
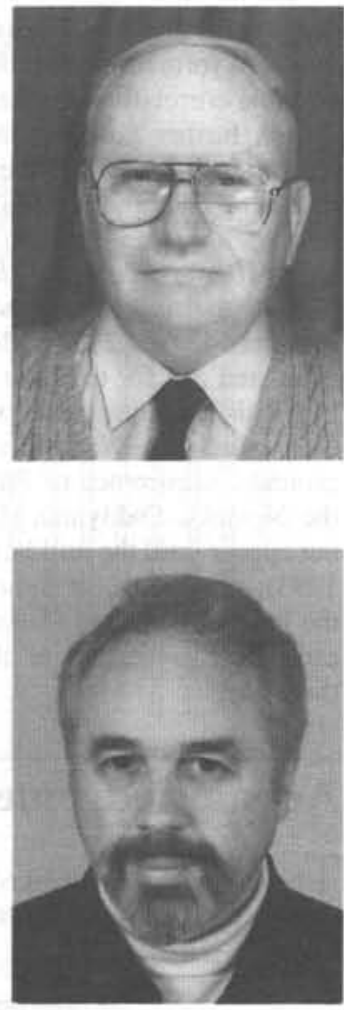

\section{Selected Middle East Papers from GEO'94}

Presented at the Middle East Geosciences Exhibition and Conference, April 1994, Bahrain. Hosted by the American Association of Petroleum Geologists, Dhahran Geological Society,

Society of Explorationists of the Emirates, Society of Exploration Geophysicists.

This two-volume coloured publication will consist of over 1000 pages with over 700 figures. 80 technical papers will cover state of the art exploration and production developments in the world's most important petroleum basin. Papers cover the petroleum systems of the Gulf countries as well as Egypt, Syria and Yemen. Topics include:

\section{- Paleozoic and Mesozoic Exploration Potential of the Middle East}

- Advances in Geophysical and Geological Technology

- 3-D Seismic Interpretation and Field Development

- Reservoir Geologic Modelling

- Advances in Reservoir Characterisation

- Depositional and Diagenetic Controls on Reservoir Distribution

- Case Histories

Papers have been reviewed by the GEO ' 94 Technical Committee and edited by Dr M I Al-Husseini

To obtain a copy of this important publication contact:

Gulf PetroLink

P O Box 20393, Manama, Bahrain

Telephone: 973214881

Facsimile: 973214475

\section{published by Gulf PetroLink}

